УДК 82I.I6І.І

ББК $83.3(2 \mathrm{Poc}=\mathrm{Pyc}) 6$
«В ЭТОЙ ЛЕГКОЙ ЦЕРКВИ -

КОРНЕЙ АРХИЕРЕЙ»: «СКВОЗНЫЕ»

ОБРАЗЫ В ПОЭЗИИ К. ЧУКОВСКОГО

И ЕГО СОВРЕМЕННИКОВ

(C) 2018 г. О.А. Симонова

Институт мировой литературы

им. А.М. Горького Российской академии наук,

Москва, Россия

Дата поступления статьи: 25 августа 2017 г.

Дата публикации: 25 июня 2018 г.

DOI: I0.22455/2500-4247-20I8-3-2-I22-I43

Исследование выполнено в ИМЛИ РАН за счет гранта

Российского научного фонда (проект №4-I8-02709)

Аннотация: В статье рассматривается поэтический портрет К.И. Чуковского. Писатель, вводя фигуру рассказчика в несколько своих сказок, заложил традицию изображения себя в качестве персонажа литературных произведений. Возникающее в поэтическом тексте лирическое «я», сопровождаемое портретом Чуковского, приобретало в восприятии читателей черты автора. Еще одним способом введения фигуры автора в текст была подача ее под маской персонажа своей сказки. Нами обнаружено неопубликованное шуточное стихотворение Чуковского, в котором он отождествляет Корнея и Бармалея. Отстраненное отношение к «Корнею», создание одноименного персонажа вызвано неполным апроприированием Чуковским своего псевдонима. Такая тенденция станет характерной для восприятия образа Чуковского его современниками, имя «Корней» будет неоднократно ими обыгрываться, отрываясь от его носителя. В статье выявляется, какие грани творчества писателя были отмечены поэтами при создании его образа. Поэты-современники Чуковского, создавая пародии на его сказки, делают писателя их героем. Пародии в силу специфики жанра заостряют черты характера поэта. Объектом описания в поэзии других авторов становится биография Чуковского. Огромный рост Чуковского впоследствии трактуется как маркер его величия, показывает, что он был современником великих людей прошлого. Образ Чуковского становится «сквозным» образом в литературе XX в.

ключевые слова: русская поэзия XX в., биография, сказки К.И. Чуковского, литературный портрет, пародии, автор, рассказчик, герой, неизвестное стихотворение Чуковского.

Информация об авторе: Ольга Алексеевна Симонова - кандидат филологических наук, старший научный сотрудник, Институт мировой литературы им. А.М. Горького Российской академии наук, ул. Поварская, д. 25 а, І2І069 г. Москва, Россия.

E-mail: osimonova@yandex.ru

Для цитирования: Симонова О.А. «В этой легкой церкви - корней архиерей»: «сквозные» образы в поэзии К. Чуковского и его современников // Studia Litterarum. 20I8. T. 3, № 2. C. I22-I43. DOI: IO.22455/2500-4247-2OI8-3-2-I22-I43 


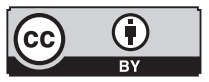

This is an open access article distributed under the Creative Commons Attribution 4.0 International (CC BY 4.0)

\section{"IN THIS LIGHT CHURCH - KORNEY IS THE HIERARCH": RECURRING IMAGES IN THE POETRY OF KORNEY CHUKOVSKY AND HIS CONTEMPORARIES}

\author{
(C) 20I8. O.A. Simonova \\ A.M. Gorky Institute of World Literature \\ of the Russian Academy of Sciences, Moscow, Russia \\ Received: August 25, 2017 \\ Date of publication: June 25, 2018
}

Acknowledgements: The research was implemented with financial support of Russian Scientific Fund (project no I4-I8-02709).

Abstract: The article examines a poetic portrait of Korney Chukovsky. By introducing the figure of the storyteller into several of his tales, the author launched a tradition of representing himself as a fictional character. Readers perceived the protagonist of his poems accompanied by his portrait as an integral authorial persona. Another way of self-presentation was through identification with fairy tale characters. In the hitherto unknown and unpublished comic poem by Chukovsky, he identifies Korney (his first name) and Barmaley (a character of his fairy tale). Chukovsky's detachment from the name Korney and the creation of the homonymous character is due to his incomplete appropriation of his pseudonym. Same tendency was typical for Chukovsky's perception by his contemporaries who developed a playful attitude to the name "Korney" and saw it as independent from its bearer. The article examines how Chukovsky's contemporaries co-created his fictional image. Writing parodies on his tales, contemporary poets represented Chukovsky as one of the characters of these parodies. Due to the specific nature of the genre, parodies sharpened certain traits of the poet's character. Chukovsky's biography also became a subject in contemporary poetry. His remarkable height stood for his own greatness and featured him as a contemporary of great people of the past. The potrayal of Chukovsky became a recurring image in the $2 \mathrm{O}^{\text {th }}$ century literature as it made its way from one work to another.

Keywords: $20^{\text {th }}$ century Russian poetry, biography, Chukovsky's tales, poetic portrait, parody, author, storyteller, character, unknown poem by Chukovsky.

Information about the author: Olga $\mathrm{A}$. Simonova, $\mathrm{PhD}$ in Philology, Senior Researcher, A.M. Gorky Institute of World Literature of the Russian Academy of Sciences, Povarskaya 25 a, I21069 Moscow, Russia.

E-mail: osimonova@yandex.ru

For citation: Simonova O.A. “ In this Light Church - Korney is the Hierarch”: recurring images in the poetry of Korney Chukovsky and his contemporaries. Studia Litterarum, 2018, vol. 3, no 2, pp. I22-I43. (In Russ.) DOI: IO.22455/2500-4247-20I8-3-2-I22-I43 
Он создан для того, чтоб на земле Его любили дети и поэты.

Ольга Дьячкова [22, с. 332]

Образ Корнея Ивановича Чуковского - детского писателя, одного из ведущих критиков начала XX в., переводчика английской поэзии, специалиста по творчеству Н.А. Некрасова, исследователя языка детей, автора воспоминаний о своих великих современниках - получил многочисленные художественные интерпретации. В статье будет рассмотрено, какие грани его творчества были отмечены поэтами - его современниками, что прежде всего запоминалось в его образе, какой в итоге получился литературный портрет Чуковского.

Визуальный образ Чуковского формировался иллюстраторами. Уже в первой его поэме для детей «Крокодил» (отдельное издание - гіл) была размещена карикатура Ре-Ми (Н.В. Ремизова). На ней Чуковский долговяз настолько, что сидит, согнувшись пополам, и держит собственные ступни руками, рядом с ним - герои сказки: Крокодил и Ваня Васильчиков (рис. г).

Чуковский сам давал повод иллюстраторам для создания своего живописного портрета. В «Крокодиле» под конец поэмы в тексте возникает лирическое «я»:

Нынче с визитом ко мне приходил -

Кто бы вы думали? - сам Крокодил.

Я усадил старика на диванчик,

Дал ему сладкого чаю стаканчик.

$$
\text { [2I, c. II8-II9] }
$$




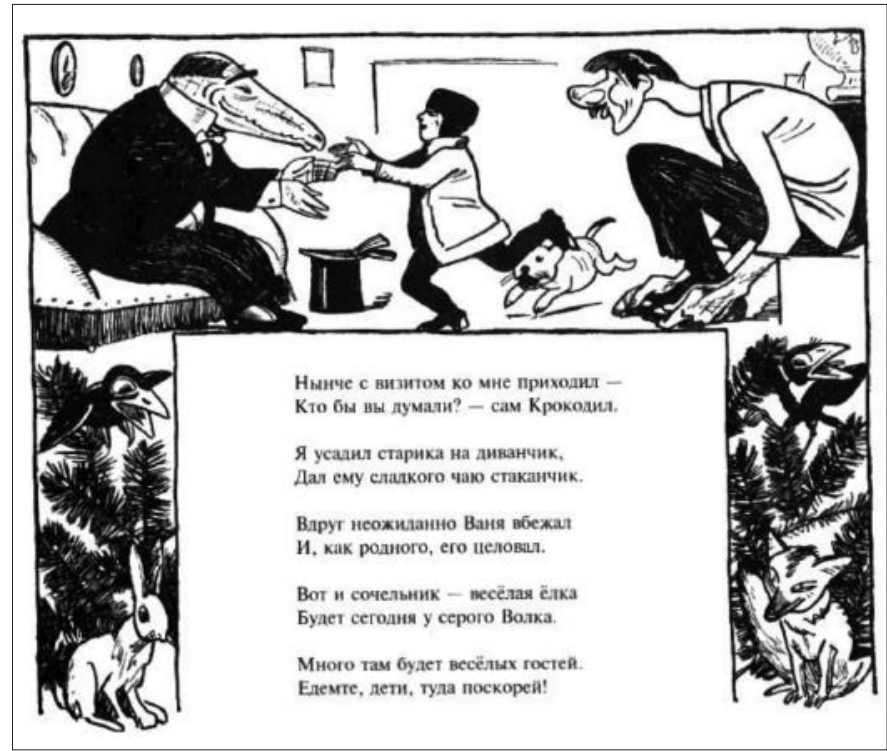

Рисунок I - Ре-Ми. Иллюстрация к «Приключениям Крокодила Крокодиловича» К. Чуковского (г919)

Re-Mi. Illustration to the "Adventures of the Crocodile Krokodilovich" by K. Chukovsky (I9I9)

Как и в нескольких других сказках Чуковского, в «Крокодиле» повествователь в какой-то момент превращается в рассказчика и на равных правах с героями начинает существовать в своем тексте. Согласно бахтинской теории, автор находится в позиции вненаходимости герою, но наделение героя своими биографическими чертами - вполне распространенное явление. Появляющийся в поэтическом тексте лирический герой, сопровождаемый портретом Чуковского, неизбежно приобретал в восприятии читателей черты автора.

Как отмечает А.А. Чевтаев, в нарративном поэтическом тексте «в структуре повествования лирический герой существует в двух функционально обусловленных проекциях: “я”-участник повествуемых событий и “я”-рассказчик» [I9]. Чуковский актуализирует обе функции лирического героя: рассказчик является действующим персонажем. В «Телефоне» Чуковский уже с первой строки нарушает границу воображаемого и реального, помещая свой образ в ткань повествования: «У меня зазвонил телефон...» (рис. 2). 


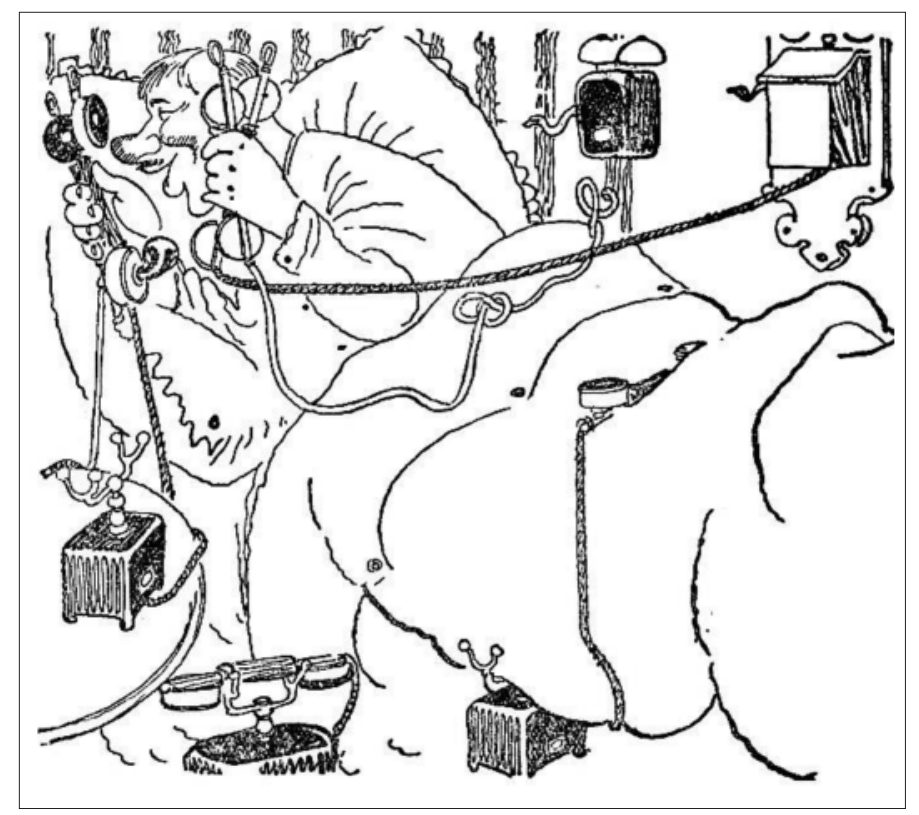

Рисунок 2 - К.П. Ротов. Иллюстрация к «Телефону» К. Чуковского (1935) K.P. Rotov. Illustration to "The telephone" by K. Chukovsky (I935)

Известно, что сказки Чуковского образуют единую повествовательную систему, в которой герои переходят из одного произведения в другое. Частью этой системы становится и сам Чуковский как герой своих сказок. В «Телефоне» рассказчик общается со своим старым знакомцем - крокодилом, который, подчеркивая это давнее знакомство, обращается к нему: «Мой милый, хороший». Автор не остается безликим, окрашивая текст биографическими подробностями. Чуковский не любил говорить по телефону, страдал бессонницей, и это выражено в сказке в усталости от бесконечного телефонного общения:

Я три ночи не спал,

Я устал.

Мне бы заснуть,

Отдохнуть... [2I, с. 87] 
Последняя сказка Чуковского «Приключения Бибигона» (1945) и автобиографична, и сказочна одновременно. Писатель поселяет сказочного персонажа Бибигона в свою действительность: «Я живу на даче в Переделкине. Это недалеко от Москвы. Вместе со мною живёт крохотный лилипут, мальчик с пальчик, которого зовут Бибигон» [2I, с. I28]. Но сказочная и реальная жизнь оказываются плохо совместимыми: В.М. Конашевич, готовивший иллюстрации к первому изданию, никак не мог добиться нужных пропорций в изображении Чуковского и лилипута (рис. 3). В героинь сказки превращаются и две внучки Чуковского - Тата и Лена (Чуковские Наталья и Елена).

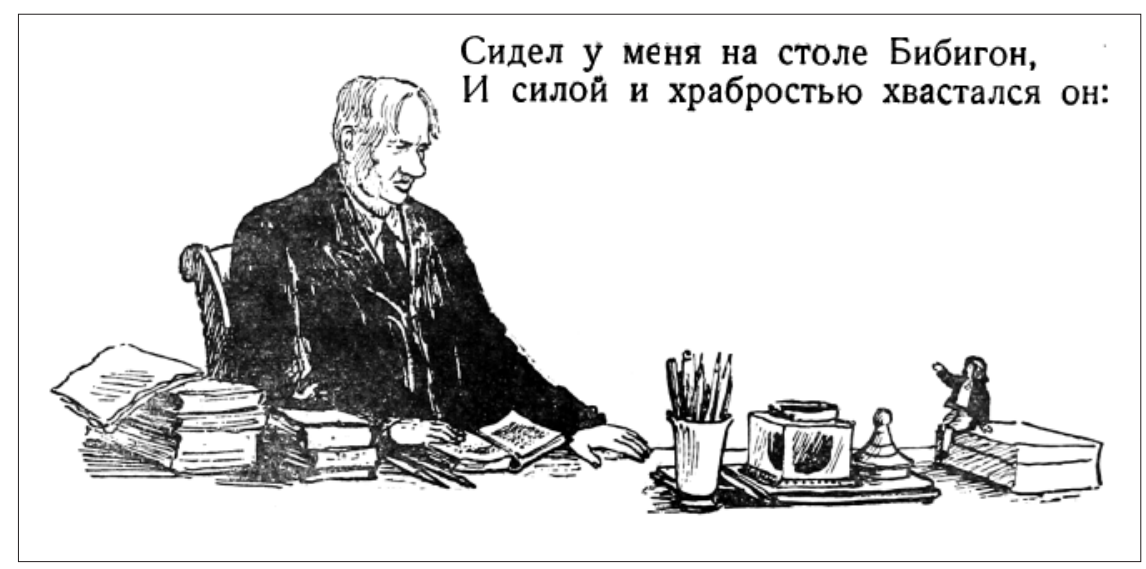

Рисунок 3 - В.М. Конашевич. Иллюстрация к «Бибигону» К. Чуковского (1956) V.M. Konashevich. Illustration to the "Bibigon" by K. Chukovsky (I956)

В «Бибигоне» рассказчик - полноправный герой повествования. Здесь происходит движение в обратную сторону - персонаж становится наблюдателем. Рассказчик оценивает поступки Бибигона, демонстрируя свою взрослость, становится воспитателем мальчика: «Что поделаешь с таким хвастунишкой! Я хотел сказать ему, что хвастаться стыдно, но он в ту же минуту умчался во двор - к новым приключениям и шалостям» [2I, c. I33]. Сказочный герой ведет себя как обычный мальчишка, вызывающий нарекания со стороны взрослого, но остается волшебным персонажем. Чуковский предлагает еще большее осуществление и воплощение сказки, 
обещая читателям-детям возможность встречи с Бибигоном и Цинцинеллой, когда рассказчик, положив их в карман своей шубы, пойдет с ними на елку в Кремль. Таким образом, в своих сказках Чуковский становится героем повествования и изобразительного ряда. Он задает тон восприятия и изображения себя в окружении своих персонажей.

Еще одним способом для Чуковского введения фигуры автора в текст является подача ее под маской одного из персонажей своих сказок. В архиве В.В. Смирновой нами обнаружено неопубликованное шуточное стихотворение Чуковского, в котором он отождествляет Корнея и Бармалея:

Вера-Верочка Смирнова,

Слишком ты ко мне сурова.

Не забыл тебя, ей-ей,

Умирающий Корней

Но сердечные припадки,

И припадки лихорадки,

Дикий кашель и колит,

Доконали Бармалея,

Злополучного Корнея,

И его не исцелит

Даже доктор Айболит.

[Около 1964]

«Корней» в этом стихотворении - не сам Чуковский, а лирический герой, известный из его сказок. Становится очевидным неполное апроприирование автором своего псевдонима, делающее возможным отстраненное отношение к «Корнею», создание одноименного персонажа. Как мы увидим ниже, такая тенденция также станет характерной для восприятия образа Чуковского его современниками, имя «Корней» будет ими неоднократно обыгрываться, отрываясь от его обладателя.

Возможно, такая раздвоенность Чуковского-писателя была обусловлена биографией. Известно, насколько мучительно воспринимал он свое положение незаконнорожденного сына, напоминание о котором преследо-

І РГАЛИ. Ф. 2847. ОП. г. Ед. хр. г4О. Л. 27. 
вало его в молодости постоянно, ведь у него не было отчества: «Все мои письма (за исключением некоторых писем к жене), все письма ко всем фальшивы, фальцетны, неискренни - именно от этого. Раздребезжилась моя “честность с собою” еще в молодости. Особенно мучительно было мне в I6-I7 лет, когда молодых людей начинают вместо простого имени называть именем-отчеством. Помню, как клоунски я просил всех даже при первом знакомстве - уже усатый - “зовите меня просто Колей”, “а я Коля” и т. д. Это казалось шутовством, но это была боль. И отсюда завелась привычка мешать боль, шутовство и ложь - никогда не показывать людям себя - отсюда пошло все остальное» [2I, т. I2, с. 2Іо].

Придумав псевдоним, Чуковский создал образ, который не полностью соответствовал его мироощущению. Чуковский постоянно рефлексировал над этой раздвоенностью, описывал конфликт между своим внешним образом и внутренним «я». Попытки показать себя «настоящего» были поступком: «Читаю Уитмэна - новый писатель. До сих пор я не заботился о том, нравится ли он мне или нет, а только о том, понравится ли он публике, если я о нем напишу. Я и сам старался нравиться не себе, а публике. А теперь мне хочется понравиться только себе, - и поэтому я впервые стал мерить Уитмэна собою» [2I, т. II, с. 205]. Двойственность писателя, умение притворяться отмечает и В.А. Каверин в предисловии к публикации его дневника [2I, т. II, с. II]. Но, подмечая двойственность в других писателях, сам Чуковский считает ее свойством таланта: «Цельность - это качество малоодаренных натур» [2I, т. II, с. 538]. Таким образом, «писатель Корней Чуковский» становится частью образа Чуковского-человека, в большинстве случаев именно эта ипостась получает жизнь в литературных произведениях других авторов.

Поэты-современники Чуковского, создавая пародии на его сказки, вслед ему делают писателя их героем. Л.А. Кассиль в стиле «Телефона» создал «Переделкинскую бибигонию» (I945), в которой обыгрывает такие черты восприятия образа Чуковского, как его популярность, сосредоточенность на своих произведениях, разнообразие интересующих его тем, стремление заработать для семьи, трудолюбие и работоспособность:

Я пишу - динь-дилень! -

День и ночь, ночь и день, 
И писать мне не лень

День и ночь, ночь и день...

Сочинил Бибигона для смеха Вам,

А теперь бы мне взяться за Чехова...

Вот и мчатся всю жизнь, друг за дружкой в угон,

Чехов, Репин, Уайльд,

Мойдодыр,

Бибигон..

Ох, нелёгкая это работа -

Целый век всё придумывать что-то... [22, с. 513]

Выдуманные персонажи ставятся в один ряд с реальными лицами, получая равные права в художественном мире, авторство которого приписывается Чуковскому. Л.Н. Лунц использует другой прием Чуковского воплощает писателя в его персонаже. Автор пародирует сказку Чуковского, используя в качестве формы стихотворения знаменитую корнееву строфу:

Жил да был крокодил,

Он по Студии ходил,

По-чуковски говорил,

Шкловитистов учил,

И меня в том числе очуковливал.

Иуда-шкловитянин

Лева Лунц [22, с. 309].

Вообще, пародий на сказки Чуковского создано огромное множество. Они заслуживают отдельного рассмотрения, мы подчеркнули только мелькающий в них образ автора. Пародии в силу специфики жанра заостряют черты характера поэта. Углубленность, погруженность писателя в интересующие его темы была подмечена А.Г. Архангельским, который назвал его «Дяденька Корнеплодий» (в пародии «Петя-детка») [г, c. 3]. Псевдоним писателя пародируется, насыщаясь новым значением: отмечено не только углубление в предмет - корень, - но и результативность этого труда - плод. 
Псевдоним становится основой для интерпретаций образа автора, порождает новые смыслы в его восприятии. Поэт А.А. Вознесенский назвал свои воспоминания о Чуковском «Человек с древесным именем», перенося метафору с имени на саму фигуру писателя: «Палка в его руке была естественным продолжением руки, суком, что ли» [6, с. 376]. Через псевдоним образ автора осмысляется и в посвящении В.А. Бабичкова:

В своих исканиях упорен,

Идет - чем больше, тем верней -

Литературы детской корень,

А может быть, еще Корней.

$$
[2, \text { c. 3] }
$$

Характерно, что здесь в ироничной форме не просто подмечена такая черта поэта, как трудолюбие, но подчеркнуто значение Чуковского как основателя советской детской литературы. Распространенность примеров обыгрывания псевдонима Корнея Чуковского позволяет утверждать, что имя стало одним из определяющих для восприятия образа писателя.

Еще одним объектом описания в поэзии других авторов становится биография Чуковского. Молодость Чуковского была отмечена карьерой критика. Как отмечает Е.В. Иванова, «Чуковский был мастером разгромного фельетона, отрицательным рецензентом по призванию» [II, с. I5], ему удавалось создавать запоминающиеся литературные портреты, вскрывающие «душу поэта». Другие авторы, в свою очередь, пытались применить метод Чуковского к его творчеству, показать его подход к литературным произведениям. Этот период оставил самые яркие изображения Чуковского в поэзии, высвечивающие портретные, биографические черты и особенности его критического голоса.

Чуковский, Аристарх прилежный,

Вы знаете - люблю давно

Я вашей злости голос нежный,

Ваш ум, веселый, как вино. 
И полной сладким ядом прозы

Приметливую остроту,

И брошенные налету

Зоилиады и занозы,

Полу-цинизм, полу-лиризм,

Очей притворчивых лукавость,

Речей сговорчивых картавость

И молодой авантюризм.

Вячеслав Иванов, Москва, І2 авг. І9І9 г. [22, с. 324]

Критические статьи Чуковский предварял публичными лекциями на те же темы, «в г9Іо-е годы лекционная деятельность набирает размах, превращаясь в настоящее публичное действо, диалог с аудиторией с эстрады, почти поединок» [го, с. I7-г8]. Лекции Чуковского были шумными, разоблачающими. В цирковых образах передает выступление пародист M.M. Бескин [15]. Стихотворение написано от лица Чуковского, который рекламирует свою лекцию, обещая разбивать о голову камни, есть куски горящей пакли и т. п. Биографическая черта - пародист отмечает речитативную речь Чуковского: «Двести сорок тысяч слов / Извергаю во мгновенье». Примечательно здесь появление героя критических разоблачений Чуковского - персонажа детективных романов - Ната Пинкертона («В заключение матчиш / Я танцую с Пинкертоном»). Матчиш - бразильский танец откровенно эротического характера, популярный в Европе в начале XX в. Таким образом, танцуя с Чуковским, выдуманный персонаж не только начинает жить в реальности критика, но Чуковский сам приравнивается к массовой, низовой культуре, которую высмеивает. Пародисты отплачивают Чуковскому его же монетой, разоблачая и низко оценивая художественный уровень его творчества, как делал и критик в своих выступлениях.

Саша Черный в стихотворении с характерным названием «Корней Белинский» подмечает особенности выступлений Чуковского: деланность, акробатичность, упор на новое, бездоказательность, легковесность утверждений, придирчивость к мелочам. Характеристиками Чуковского становятся приверженность внешним эффектам, чрезмерное внимание к вещам, которые того не заслуживают: «Иногда Корней Белинский / Сечет господ, цена кото- 
рым грош». Саша Черный также уравнивает Чуковского с героями его критических выступлений. Так, экзотика, которую Чуковский находит в стиле популярных писателей, является особенностью и его стиля, в устах Саши Черного:

В экзотике заглавий - пол-успеха.

Пусть в ноздри бьет за тысячу шагов:

«Корявый буйвол», «Окуни без меха»,

«Семен Юшкевич и охапка дров».

$[20$, c. 5]

По одной из версий, именно Чуковского изобразил В.В. Маяковский в своем «Гимне критику»:

От страсти извозчика и разговорчивой прачки невзрачный детеныш в результате вытек.

Мальчик - не мусор, не вывезешь на тачке.

Мать поплакала и назвала его: критик.

[I4, c. 82]

Совпадают факты биографии: Чуковский был незаконнорожденным сыном, мать его работала прачкой. Е.В. Иванова полагает, что, скорее всего, Чуковский сразу после написания стихотворения осознал оскорбительность послания, в связи с чем рассорился с Маяковским [І2].

Период гражданской войны начала І920-х гг., когда Чуковский, как и другие литераторы, вел литературные кружки в разных новообразованных учреждениях, запечатлен в эпиграмме Н.О. Лернера: «Пред чрезвычайными чухонцами / Поет Корней» [22, с. 275]. Здесь, как мы отмечали и выше, уже одно имя представляет Чуковского.

Чуковский фигурирует в стихотворениях и как издатель произведений Н.А. Некрасова. Многолетнее изучение наследия Некрасова стало, по признанию Чуковского, главным трудом его жизни: «Было приятно уйти от суетливой и пестрой газетно-журнальной поденщины к научной сосредоточенной деятельности» [2I, с. 9]. Но и здесь проявились та живость, активность и стремительность Чуковского, которые были свойственны ему как критику. В шутливом стихотворении Л.М. Варковицкой І927 г. запечатлен 
эпизод, когда Чуковский пришел вычитывать Некрасова и оказался в буфете Госиздата:

Учуял ли Чуковский нюхом,

Что дали корректуру нам,

Иль просто заскучало брюхо

По Госиздатским пирожкам,

Но он пришел, сидит в буфете

Дань отдает свиной котлете,

В то время как двадцатый лист

Как вешний снег нетронут, чист.

И ждут Корнеевой руки

Некрасовские мужики.

$$
\text { [5, c. 98] }
$$

И если в этом стихотворении Чуковский предпочитает корректуре котлету, то в стихотворении Ал. Флита «Некрасов и двое других. Чуковский и Евгеньев-Максимов» он въедливо изучает творчество поэта:

Дожили оба до седин,

Но нет в работе их покоя:

Поэт Некрасов был один,

«Некрасоедов» - целых двое!

[18, c. I66]

Еще более биографичны посвящения, запечатлевшие отдельные моменты жизни Чуковского, они создают своеобразную поэтическую хронику жизни писателя. Пребывание поэта в санатории Узкое в I940 г. отразилось в «Балладе» В.И. Рубина:

В санатории плач, в санатории вой,

Потрясен он до самых корней.

Покидает всех нас, уезжает домой

Наш любимый Чуковский Корней.

[22, c. 500] 
После отъезда Чуковского его примеру следуют другие отдыхающие, и советский санаторий постепенно зарастает волшебным лесом. Вернуть его к жизни может только Чуковский. Так писатель становится, подобно принцу из «Спящей красавицы», героем, способным победить сон и возродить людей к жизни. Эпизод его биографии превращается в сказку. Рубин, делая писателя сказочным персонажем, продолжает предложенную Чуковским игру.

Эвакуация в Ташкент нашла отражение в стихотворениях В.Д. Берестова и В.В. Левика. В г942 г. Берестов, отмечая огромную разницу в возрасте («Мне четырнадцать лет, а ему шестьдесят»), пытается поставить себя рядом с Чуковским, ведь у них общий язык - поэзии:

О поэзия! Души людей береди,

Чтоб нашли в тебе силы и общий язык

Этот хилый мальчишка и крепкий старик.

$$
\text { [3, с. II8] }
$$

Это стихотворение, аккумулировав историю знакомства будущего поэта со знаменитым писателем, впоследствии стало основой для воспоминаний Берестова «Совсем недавно был Корней Иванович», в которых та же история получила уже развернутое воплощение. Любопытно, что в воспоминаниях заимствуются фразы из стихотворения, например: «Между нами бездна: в один и тот же весенний день ему стукнуло шестьдесят, а мне четырнадцать» [4, с. I34]. О Ташкенте писал в 1942 г. и В. Левик:

И, право, сей Ташкент - кудесник:

Едва в одну попали грязь,

Тотчас же обрели мы связь.

[22, c. 508]

Злой и острый язык Чуковского вынуждал многих поэтов придерживать свой за зубами. В посвящении I945 г. Левик будто отказывается писать Корнею Чуковскому, «который может съесть живьем» [22, с. 508]. По-видимому, многие авторы, боясь получить колкость в ответ, в своих посвящениях сглаживали образ Чуковского. 
Типичной характеристикой автора в восприятии современниками становится его внешний вид. Внешность Чуковского была очень примечательна. Крупные черты лица, длинные руки с большими кистями, высокий рост, нос, прядь волос, которая свисает на лоб. Все это давало пищу для шаржей и карикатур. Его портреты создали В.В. Маяковский, Ре-Ми, М.В. Добужинский, А.М. Любимов, Ю.П. Анненков, П.Н. Троянский, К.И. Рудаков, А.М. Арнштам, С.В. Чехонин, Кукрыниксы и др. От застенчивости он горбился: на карикатурах часто изображается похожим на букву «Г». Схожим образом создается портрет Чуковского в поэзии. В «Оде» Ольги Дьячковой:

Идет. Еще один аршинный шаг -

И на столе живут большие руки

Вокруг больших внушительных бумаг.

[22, c. 332]

В буримэ М.Л. Слонимского «На встрече Нового года» (I919-I920):

И длиннорук, как канделябр,

И громогласней громких арий,

Длиннее самых длинных швабр,

Он радостен, как пролетарий.

[22, c. 334]

Больше всего обращал на себя внимание огромный рост Чуковского. В I902 г. друг писателя В.Е. Жаботинский писал:

Чуковский Корней,

Таланта хваленого,

В два раза длинней

Столба телефонного.

$$
\text { [9, c. 45] }
$$

Впоследствии рост писателя становится маркером его величия, показывает, что он был современником великих людей прошлого, «ровесник разных поколений»: 
И на тебя, как на вершину,

Всегда смотрел я снизу вверх.

И всякий раз при нашей встрече

Сходились, как в былые дни,

Мои великие предтечи.

Друзья старинные твои.

И не меня ль на перевале

Венчал ты, будто бы Казбек,

Рукой, которую пожали

Минувший и двадцатый век.

Р.Г. Гамзатов

[7, c. I3]

Для поэтов, знавших Чуковского в конце его жизни, он становится великим старцем, наделяется чертами, которых у него не было, которые обычно приписывают человеку именно в преклонном возрасте. Поэтому у Гамзатова он назван «бедовый и вещий Старик» (с заглавной буквы), атрибутом его становится «посох». Е.А. Евтушенко и Гамзатов называют его в своих стихотворениях «добрым гением». Писатель мифологизируется вплоть до того, что становится олицетворением «совести нации», носителем истины в литературе. У Гамзатова:

Причастный к событиям многим,

Судьбою ты был возносим,

Как мудрость над знаньем убогим,

Как совесть над словом кривым.

$[7$, c. I2]

Для передачи той же мысли Евтушенко в стихотворении «Паруса» (I969) использует образы поэзии Чуковского, вновь совмещая образы автора и его героя: 
Но он юно, изящно и весело

фехтовал до конца своих дней,

Айболит нашей русской словесности,

с бармалействующими в ней.

$$
[8, \text { c. 472] }
$$

В стихотворении «Переделкино» Евтушенко подчеркивает сочетание старости и юношеской легкости Чуковского, создавая образ «старейшего юноши в стране». Здесь Евтушенко обращается не к произведениям Чуковского, а к его знаменитым словам «В России надо жить долго», перефразируя их и хронологически конкретизируя: «Всем людям, а особенно писателям / в двадцатом веке надо долго жить» [22, с. 549]. Таким образом, Чуковский выступает как автор афоризмов, носитель мудрости, еще больше воплощая создаваемый его младшими современниками образ великого старца. Возникает фигура патриарха литературы, который, по выражению С.С. Смирнова, был «со столетием на “ты” $[$ г7, с. 88].

Как известно, другим патриархом советской детской литературы был С.Я. Маршак. Сложные отношения дружбы-соперничества складывались у него с Чуковским. Маршак вспоминает о появлении Чуковского в литературе - «молодого, веселого, буйного, дерзкого критика», «который, книгу разобрав / Подчас бывает и неправ», «лукавый, ласковый и злой» [13, с. 560-56г]. Но, конечно, наибольшей заслугой ему видятся сказки Чуковского. И именно в окружении детей мыслит он поэта. Цитируя название книги Чуковского, он, будто насмехаясь, отрицает возраст юбиляра:

Могу я дать тебе - прости! -

От двух, примерно, до пяти...

$[\mathrm{I} 3$, c. 56I]

Возраст становится одной из характеристик Чуковского, так как многие стихотворения Маршака написаны по случаю юбилеев.

Вижу: Чуковского мне не догнать.

Пусть небеса нас рассудят!

Было Чуковскому семьдесят пять, 
Скоро мне столько же будет.

Глядь, от меня ускакал он опять,

Снова готов к юбилею...

Ежели стукнет мне тысяча пять,

Тысяча десять - Корнею!

$$
\text { [13, c. 59I] }
$$

$* * *$

Пять лет, шесть месяцев, три дня

Ты прожил в мире без меня.

$$
\text { [I3, с. 560] }
$$

Эти стихотворения, хоть и в шутливой форме, неизменно подчеркивают превосходство по старшинству юбиляра. Маршак пытается всячески это превосходство сгладить. Он неоднократно подчеркивает общность судьбы: гонения чиновников от педагогики и литературоведения, общая читательская аудитория, долголетие в литературе. Об этом речь в стихотворении «Корнею Ивановичу Чуковскому»:

Тебя терзали много лет

Сухой педолог-буквоед

И буквоед-некрасовед,

Считавший, что науки

Не может быть без скуки.

Кощеи эти и меня

Терзали и тревожили,

И все ж до нынешнего дня

С тобой мы оба дожили.

Могли погибнуть ты и я,

Но, к счастью, есть на свете

У нас могучие друзья,

Которым имя - дети!

[I3, c. 584] 
Маршак подчеркивает их одинаковый статус. Идея чаемого равенства выражена Маршаком и стилистически (Корней Иванович Чуковский, / Прими привет мой Маршаковский!) [13, с. 560]. Маркером их единения и равенства, естественно, становятся «общие дети»:

Мы - братья по перу, отчасти и родня.

Одна у нас семья: одни и те же дети

В любом краю страны у Вас и у меня.

$$
\text { [22, c. 552] }
$$

Итак, Чуковский на протяжении всего его творчества воспринимался другими поэтами неотделимо от своих персонажей. В молодости приравнивался к авторам и героям массовой литературы, которую критиковал. Впоследствии становится персонажем пародий на его сказки. Поэты не просто продолжают предложенную Чуковским игру по превращению его в героя сказок, но заимствуют стиль и форму его сказок. Образ Чуковского становится «сквозным» образом в литературе XX в., переходя из произведения в произведение. В конце жизни Чуковский стал восприниматься патриархом детской литературы:

Детская поэзия: хорей, хорей, хорей.

Все куда-то торопятся: скорей, скорей, скорей!

В этой легкой церкви - Корней архиерей.

Смотрите: он устраивает

ревучий рай зверей.

$$
\text { [16, с. 29] }
$$

\section{Список литературы}

I А Ахангельский А. Петя-детка («Петя-детка заскучал...») // Литературная газета. 1932. 23 нояб. С. 3.

2 Бабичков В.К. Чуковскому («В своих исканиях упорен...») // Литературная газета. I963. 2 г мая. С. 3 .

3 Берестов В.Д. Избранные произведения: в 2 т. М.: Вагриус, Изд-во им. Сабашниковых, І998. Т. 2: Стихи, повести, рассказы, воспоминания. 606 с. 
Берестов В.Д. Совсем недавно был Корней Иванович... // Воспоминания о Корнее Чуковском / сост. К.И. Лозовская и др. М.: Сов. писатель, І983. С. І28-I4I. Варковицкая Л. «Госиздатские пирожки» // Воспоминания о Корнее Чуковском / сост. К.И. Лозовская и др. М.: Сов. писатель, г983. С. 96-99. Вознесенский А. Человек с древесным именем // Воспоминания о Корнее Чуковском / сост. К.И. Лозовская и др. М.: Сов. писатель, І983. С. 376-378. Гамзатов Р.Г. Собр. соч.: в 5 т. М.: Худож. лит., І982. Т. 5: Стихотворения. Поэмы. Верность таланту. 575 с.

8 Евтушенко Е. Паруса: Памяти К. Чуковского // Воспоминания о Корнее Чуковском / сост. К.И. Лозовская и др. М.: Сов. писатель, І983. С. 47І-472.

9 Жаботинский В. «Чуковский Корней...» // В ст. В. Глоцера «Он “Великий Умывальник, Знаменитый Мойдодыр”» // Жизнь и творчество Корнея Чуковского. М.: Просвещение, 1978. С. 45.

Iо Иванова Е. Годы известности Чуковского-критика // Чуковский К.И. Собр. соч.: в I5 т. М.: Терра-Книжный клуб, 2003. Т. 7 / предисл. и коммент. Е. Ивановой. C. $5^{-22 .}$ Иванова Е.В. Неизвестный Чуковский // Чуковский К.И. Собр. соч.: в 15 т. М.: Терра-Книжный клуб, 2002. Т. 6 / предисл. и коммент. Е. Ивановой. С. 5-26. Иванова Е.В. Чуковский - Харджиев - Маяковский: О ком был написан «Гимн критику»? // Вопросы литературы. 2014. № 6. С. І96-2І17.

I3 Маршак С.Я. Собр. соч.: в 8 т. М.: Худож. лит., І97О. Т. 5 / подг. текста и прим. В.Г. Титовой. 704 с.

I4 Маяковский В.В. Полн. собр. соч.: в г3 т. М.: ГИХЛ, І955. Т. г / подг. текста и прим. В.А. Катаняна. 464 с.

I5 Меб (Бескин М.М.). Одно другого стоит: Чуковский - о своей лекции («Не бывало до сих пор!!!.») // Раннее утро. г908. г нояб.

I6 Слуцкий Б. Детская литература // Детская литература. I993. № I. С. 29.

I7 Смирнов С., Игин И. Добро обжаловать... Пародии, шаржи, эпиграммы. М.: Мол. гвардия, І962. 96 с.

I8 Флит А. Некрасов и двое других: Чуковский и Евгеньев-Максимов // Флит A. Таланты наизнанку. Л.: ГИХЛ, І940. 176 с.

I9 Чевтаев A.A. Герой в нарративной лирике: структура и аксиология // Narratorium. 2OII. № I-2. URL: http://narratorium.rggu.ru/article.html?id=2027602 (дата обращения: 20.08.20I7)

20 Черный Саша. Корней Белинский (Опыт критического шаржа) («В экзотике заглавий - пол-успеха...») // Сатирикон. г9гі. № II. С. 5 .

2I Чуковский К.И. Собр. соч.: в І5 т. М.: Терра - Книжный клуб, 200I-2009.

22 Чукоккала: Рукописный альманах Корнея Чуковского / коммент. К. Чуковского, сост., подгот. текста и прим. Е. Чуковской. М.: Русский путь, 2006. 584 с. 


\section{References}

I Arkhangel'skii A. Petia-detka («Petia-detka zaskuchal...») [Petya-baby "Petya-baby is bored”]. Literaturnaia gazeta, I932, November 23, p. 3. (In Russ.) Babichkov V. K. Chukovskomu ("V svoikh iskaniiakh uporen...”) [To Chukovsky (“Persistent in his search...”)]. Literaturnaia gazeta, I963, May 2I, p. 3. (In Russ.)

3 Berestov V.D. Izbrannye proizvedeniia: $v 2 t$. [Selected works: in 2 vols.]. Moscow, Vagrius, Izdatel'stvo im. Sabashnikovykh Publ., I998. Vol. 2. Stikhi, povesti, rasskazy, vospominaniia [Poems, novels, stories, and memoir]. 606 p. (In Russ.) Berestov V.D. Sovsem nedavno byl Kornei Ivanovich... [Just recently, he has been Korney Ivanovich...]. Vospominaniia o Kornee Chukovskom [Memoir about Korney Chukovsky], ed. K.I. Lozovskaya and others, ed. 2. Moscow, Sov. pisatel' Publ., I983, pp. I28-I4I. (In Russ.)

5 Varkovitskaia L. "Gosizdatskie pirozhki” ["Gosizdat pies”]. Vospominaniia o Kornee Chukovskom [Memoir about Korney Chukovsky], composed by K.I. Lozovskaya and others, ed. 2. Moscow, Sov. pisatel' Publ., I983, pp. 96-99. (In Russ.)

6 Voznesenskii A. Chelovek s drevesnym imenem [The man with a wooden name]. Vospominaniia o Kornee Chukovskom [Memoir about Korney Chukovsky], ed. K.I. Lozovskaya and others, ed. 2. Moscow, Sov. pisatel' Publ., I983, pp. 376-378. (In Russ.)

7 Gamzatov R.G. Sobranie sochinenii: $v 5$ t. [Collected works: in 5 vols.]. Moscow, Khud. lit. Publ., I982. Vol. 5: Stikhotvoreniia. Poemy. Vernost' talantu [Verses. Poems. Fidelity to the talent]. 575 p. (In Russ.)

8 Evtushenko E. Parusa: Pamiati K. Chukovskogo [Sails: To the memory of K. Chukovsky]. Vospominaniia o Kornee Chukovskom [Memoir about Korney Chukovsky], ed. by K.I. Lozovskaya and others, ed. 2. Moscow, Sov. pisatel' Publ., I983, pp. 47I-472. (In Russ.)

9 Zhabotinskii V. “Chukovskii Kornei...”. V stat'e V. Glotsera “On „Velikii Umyval’nik, Znamenityi Moidodyr"” [In V. Glotzer's article "He is the Great Wash-Basin, the Famous Moydodyr"]. Zhizn' i tvorchestvo Korneia Chukovskogo [Life and work of Korney Chukovsky]. Moscow, Prosveshchenie Publ., 1978, p. 45. (In Russ.)

Io Ivanova E. Gody izvestnosti Chukovskogo-kritika [Years of Chukovsky's fame as a critic]. Chukovskii K.I. Sobranie sochinenii: $v$ I5 $t$. [Collected works: in I5 vols.], preface and comments by E. Ivanova. Moscow, Terra-Knizhnyi klub Publ., 2003, vol. 7, pp. 5-22. (In Russ.)

II Ivanova E.V. Neizvestnyi Chukovskii [Unknown Chukovsky]. Chukovskii K.I. Sobranie sochinenii: $v$ I5 t. [Collected works: in I5 vols.], preface and comments by E. Ivanova. Moscow, Terra-Knizhnyi klub Publ., 2002, vol. 6, pp. 5-26. (In Russ.)

I2 Ivanova E.V. Chukovskii - Khardzhiev - Maiakovskii: O kom byl napisan "Gimn kritiku"? [Chukovsky - Khardzhiev - Mayakovsky: About whom "The hymn to the critic” was written]. Voprosy literatury, 20I4, no 6, pp. I96-2I7. (In Russ.) 
I3 Marshak S.Ia. Sobranie sochinenii: $v 8 t$. [Collected works: in 8 vols.], ed. and notes by V.G. Titova. Moscow, Khud. lit. Publ., I970. Vol. 5.704 p. (In Russ.)

I4 Maiakovskii V.V. Polnoe sobranie sochinenii: $v$ I3 $t$. [Complete works: in I3 vols.], ed. and notes by V.A. Katanian. Moscow, GIKhL Publ., I955. Vol. I. 464 p. (In Russ.)

I5 Meb (Beskin M.M.). Odno drugogo stoit: Chukovskii - o svoei lektsii ("Ne byvalo do sikh por!!!..”) [Birds of a feather: Chukovsky about his lecture ("This has never happened until now!!!..”)]. Rannee utro, I908, November I. (In Russ.)

I6 Slutskii B. Detskaia literatura [Children's literature]. Detskaia literatura, I993, no I, p. 29. (In Russ.)

I7 Smirnov S., Igin I. Dobro obzhalovat'... Parodii, sharzhi, epigrammy [Welcome to appeal... Parodies, cartoons, and epigrams]. Moscow, Mol. gvardiia Publ., I962. 96 p. (In Russ.)

I8 Flit A. Nekrasov i dvoe drugikh: Chukovskii i Evgen'ev-Maksimov [Nekrasov and two others: Chukovsky and Evgen'ev-Maksimov]. Flit A. Talanty naiznanku [Talents insideout]. Leningrad, GIKhL Publ., I940. I76 p. (In Russ.)

I9 Chevtaev A.A. Geroi v narrativnoi lirike: struktura i aksiologiia [Character in the narrative lyrics: structure and axiology]. Narratorium, 20II, no I-2. Available at: http://narratorium.rggu.ru/article.html?id=2027602 (Accessed 20 August 2017) (In Russ.)

20 Chernyi Sasha. Kornei Belinskii (Opyt kriticheskogo sharzha) ("V ekzotike zaglavii pol-uspekha...”) [Korney Belinsky (Experience of the critical cartoon) ("Exotic titles are half-success...")]. Satirikon, I9II, no II, p. 5. (In Russ.)

2I Chukovskii K.I. Sobranie sochinenii: $v$ I5 t. [Collected works: in I5 vols.]. Moscow, Terra - Knizhnyi klub Publ., 200I-2009. (In Russ.)

22 Chukokkala: Rukopisnyi al'manakh Korneia Chukovskogo [Chukokkala: The Handwritten Almanac of Korney Chukovsky], comments by K. Chukovsky, composed, ed. and notes by E. Chukovskaya. Moscow, Russkii put' Publ., 2006. 584 p. (In Russ.) 